\title{
Expression of Interleukin 2 Receptors by Monocytes from Patients with Acquired Immunodeficiency Syndrome and Induction of Monocyte Interleukin 2 Receptors by Human Immunodeficiency Virus In Vitro
}

\author{
J. B. Allen," N. McCartney-Francis," P. D. Smith," G. Simon," S. Gartner,” L. M. Wahl," M. Popovic, \\ *Cellular Immunology Section, Laboratory of Immunology, NIDR and ${ }^{\S}$ Laboratory of Tumor Cell Biology, National Cancer Institute, \\ National Institutes of Health, Bethesda, Maryland 20892; and ${ }^{\ddagger}$ Department of Medicine, George Washington University \\ Medical Center, Washington, District of Columbia 20037
}

\begin{abstract}
A population of circulating mononuclear cells from patients with AIDS was identified which expressed interleukin 2 receptors (IL-2R). By dual-fiuorescence flow microfluorometry, the patients' IL-2R ${ }^{+}$cells were further identified as Leu $\mathrm{M3}^{+}$ monocytes $\left(29.4 \pm 5.2 \%\right.$ of the Leu $\mathrm{M3}^{+}$cells were IL-2R ${ }^{+}, n$ $=15$ ), whereas Leu $\mathrm{M3}^{+}$monocytes from normal subjects were IL-2R negative $(2.0 \pm 0.42 \% ; P<0.001)$. By Northern analysis, monocytes from AIDS patients, but not control subjects, constitutively expressed steady-state levels of IL-2R mRNA. Functionally, the $I L-2 R^{+}$monocytes were capable of depleting IL-2 from culture supernatants, suggesting a mechanism for the reduced IL-2 levels commonly seen in AIDS patients. IL-2R ${ }^{+}$monocytes also expressed increased levels of surface HLA-DR which may favor monocyte $T$-cell interactions and the transmission of human immunodeficiency virus (HIV). In additional studies, normal monocytes were infected with a macrophage-tropic HIV isolate in vitro and monitored for IL-2R and HLA-DR expression. Within 24-48 $\mathrm{h}$ after exposure to HIV in vitro, but before evidence of productive infection, $>25 \%$ of the monocytes became IL-2 ${ }^{+}$with increasing numbers of IL-2R ${ }^{+}$cells and HLA-DR levels through day 6 . These early signaling effects of HIV could be mimicked by adding purified HIV envelope glycoprotein gp1 20 to the monocytes. This stimulation of monocytes before or independent of productive infection of the cells by HIV is consistent with in vivo observations of activated and/or abnormal functions by monocytes that do not appear to be infected with HIV in AIDS patients. (J. Clin. Invest. 1990. 85:192-199.) acquired immunodeficiency syndrome $\bullet$ human immunodeficiency virus $\bullet$ interleukin 2 - interleukin 2 receptor - monocyte/macrophage
\end{abstract}

\section{Introduction}

The central role of monocyte/macrophages in immunologic events suggests that these cells may play an important role in the pathogenesis of the acquired immunodeficiency syndrome (AIDS). The human immunodeficiency virus (HIV) infects CD4 positive lymphocytes (1-3) as well as cells of monocyte/ macrophage lineage, including peripheral blood monocytes (4-8) and tissue macrophages (9-15) that also express CD4 receptors. Monocytes obtained from patients with AIDS ex-

Address reprint requests to Dr. S. M. Wahl, Building 30, Room 326, National Institute of Dental Research, Bethesda, MD 20892. 1989.

Received for publication 12 May 1989 and in revised form 25 July

The Journal of Clinical Investigation, Inc.

Volume 85, January 1990, 192-199 hibit phenotypic and functional abnormalities (16), some of which are consistent with an activated state of the circulating monocytes (17). In this regard, monocytes from AIDS patients may express altered levels of surface $\operatorname{HLA}-D R(18,19)$ and chemotactic ligand receptors $(8,20)$, and increased levels of IL-1 (21-23).

Monocyte dysfunction also has been associated with impaired $T$ cell proliferative responses in $\operatorname{AIDS}$ patients $(24,25)$. Two critical requirements for $T$ cell proliferation, the secretion of interleukin 2 (IL-2) and the expression of surface IL-2 receptors (IL-2R) ${ }^{1}$ on T cells, are impaired in AIDS patients (26-28). The decreased IL-2 could be due to reduced production or to increased depletion. Soluble IL-2R which can bind IL-2 (29) have been identified in sera from HIV-seropositive persons (30-33), providing a mechanism for IL-2 depletion. Additionally, the diminished levels of IL-2 detected in AIDS patients could be the consequence of IL-2 binding and/or metabolism by monocytes, since activated monocytes express functional IL-2R (34-36). Although the increased levels of soluble IL-2R are commonly presumed to be the consequence of shedding by activated CD4 positive lymphocytes (37), activated monocytes may also release IL- $2 R$ into the serum. In the present study, we demonstrate for the first time that peripheral blood monocytes from patients with AIDS express significant levels of IL-2R, that this may be an important mechanism for IL-2 depletion, and furthermore, that HIV can directly induce IL-2R expression on monocytes in vitro.

\section{Methods}

Patients. The study included 22 homosexual males with AIDS. Of these patients, 1 was asymptomatic, 7 had Kaposi's sarcoma, and 14 had one or more opportunistic infections. None of the patients had known bacterial infections. No patient was on immunomodulatory or antiviral therapy at the time of study. Control subjects were 22 healthy seronegative heterosexual adults.

Mononuclear leukocyte suspensions. Mononuclear leukocytes (MNL) isolated from heparinized peripheral blood of patients and control subjects by Ficoll-Paque sedimentation were washed and suspended in Dulbecco's modified Eagle's medium (DME, Gibco Laboratories, Grand Island, NY) containing $50 \mu \mathrm{g} / \mathrm{ml}$ gentamicin and $2 \mathrm{mM}$ glutamine. Total MNL, monocyte, and lymphocyte numbers were determined by Coulter Counter size analysis (Coulter Electronics Inc., Hialeah, FL) and phenotypic staining (see below). To obtain highly purified populations of monocytes and lymphocytes, MNL from leukapheresis preparations of healthy control subjects (National Institutes of Health Blood Bank) were separated by counterflow centrifugal elutriation (CCE) (38).

1. Abbreviations used in this paper: $\mathrm{CCE}$, counterflow centrifugal elutriation; FMF, fluorescence flow microfluometry; IL-2R, interleukin 2 receptors; MNL, mononuclear leukocyte(s); RMFI, relative median fluorescence intensity. 
Labeling of cell surface antigens. Single cell suspensions $(50 \mu \mathrm{l})$ of MNL or CCE-purified monocytes diluted $10 \times 10^{6} / \mathrm{ml}$ in phosphatebuffered saline (PBS) with $0.1 \%$ sodium azide and $2 \%$ fetal calf serum (FCS) were incubated at $4^{\circ} \mathrm{C}$ for $30 \mathrm{~min}$ with fluorescein isothiocyanate (FITC)-conjugated monoclonal antibodies directed against Leu M3 (monocytes), HLA-DR, Leu 1 (T lymphocytes), and IL-2R or with phycoerythrin-conjugated HLA-DR, Leu M3, and IL-2R antibodies (Becton-Dickinson Monoclonal Center, Inc., Mountain View, CA) (35). Human AB serum (10\%) was added to the cells 10 min before incubation with the monoclonal antibodies to prevent nonspecific binding to Fc receptors. After staining, the cells were washed twice with buffer without FCS and immediately resuspended in $0.5 \mathrm{ml}$ of $2 \%$ paraformaldehyde at $4^{\circ} \mathrm{C}$ until analysis by flow microfluorometry (FMF) with a FACStar cell sorter (Becton-Dickinson).

Northern blot analysis of monocyte $m R N A$. Total RNA was extracted by the guanidine thiocyanate method from 5-10 $\times 10^{6}$ adherent monocytes from patients or normal individuals cultured $14 \mathrm{~h}$ with or without lipopolysaccharide (LPS, $10 \mu \mathrm{g} / \mathrm{ml}$, Escherichia coli 055:B5, Difco Laboratories, Inc., Detroit, MI) (35). RNA (5 $\mu \mathrm{g})$ was electrophoresed in a formaldehyde-containing agarose gel, transferred to nitrocellulose paper and hybridized with a ${ }^{32}$ P-labeled EcoR 1 insert of pIL2R2c obtained from W. Leonard, National Institute of Child Health and Human Development (39). The probe was nick-translated with $\left[\alpha_{-}{ }^{32}\right.$ P]dCTP (Amersham, Arlington Heights, IL) after which the labeled probe was purified by gel filtration. The filters were exposed to XAR-5 film (Eastman Kodak Co., Rochester, NY) with intensifier screens at $-70^{\circ} \mathrm{C}$ for $3 \mathrm{~d}$. The ethidium bromide staining pattern of the $28 \mathrm{~S}$ and $18 \mathrm{~S}$ ribosomal RNA bands indicated equivalent amounts of RNA loaded in each lane.

IL-2 depletion and quantitation. Adherent monocytes from AIDS patients and normal individuals $\left(2 \times 10^{6} / \mathrm{ml}\right)$ were cultured for $24-72$ $h$ in the presence of varying concentrations of recombinant IL-2 (Genzyme, Boston, MA). The cell-free supernatants were harvested and assayed for IL-2 activity by their ability to support the growth of the murine IL-2-dependent CTLL-2 cell line (40). The CTLL-2 cells were cultured for $48 \mathrm{~h}$ in the presence of threefold dilutions of the test samples in parallel with an IL-2 standard $(100 \mathrm{U} / \mathrm{ml}$, Genzyme). After a 4-h pulse with $0.5 \mu \mathrm{Ci}$ of $\left[{ }^{3} \mathrm{H}\right] \mathrm{TdR}$ (sp act $1.9 \mathrm{Ci} / \mathrm{mM}$, SchwarzMann, Orangeburg, NY), the incorporated radioactivity was determined.

In vitro infection with HIV-1. CCE-purified normal monocytes $\left(>95 \%\right.$ Leu $\left.\mathrm{M}^{+}\right)$were suspended $\left(10 \times 10^{6}\right)$ in $1 \mathrm{ml}$ of supernatant containing HIV-1/HTLV-III $\mathrm{Ba}_{\mathrm{L}-\mathrm{L}}\left(5 \times 10^{5} \mathrm{cpm}\right.$ reverse transcriptase), an isolate derived from alveolar macrophages of a patient with AIDS (6), as previously described (8). Control monocytes were suspended in RPMI 1640 (Gibco Laboratories) containing 20\% FCS, and/or in supernatant without virus for $1 \mathrm{~h}$ with intermittent shaking at $37^{\circ} \mathrm{C}$. The cells were washed and resuspended in RPMI 1640 containing 10\% FCS, antibiotics, and glutamine. After incubation in suspension at $37^{\circ} \mathrm{C}$ for varying intervals, the monocytes were analyzed for surface antigen expression. Viral infection was confirmed by determining p24 and reverse transcriptase levels and by ultrastructural evaluation of parallel adherent monocyte cultures as previously described (8).

Treatment of monocytes with gp1 20 and anti-CD4a. In additional studies, CCE-purified normal monocytes were cultured in suspension with purified HIV-1 envelope glycoprotein gp 120 or the core protein p24. The gp 120 was isolated from the culture fluids or cell membrane extracts of HIV-1/HTLV-III ${ }_{B}$ or HIV-1/HTLV-III ${ }_{R F}$ infected $\mathrm{H} 9$ cells by immunoaffinity chromatography (41) and the core protein p24 was purified as described (42). For some assays, the gp120 was immunoprecipitated with goat anti-gp120 sera (8). At the highest concentrations tested these preparations had $<0.2 \mathrm{ng} / \mathrm{ml}$ of endotoxin as determined by the Limulus amebocyte lysate assay.

Under similar conditions, monocytes were cultured in the presence of varying concentrations of antibody directed at the CD4 receptor (OKT4A, Ortho Diagnostics, Raritan, NJ) or with the isotype control $\left(\mathrm{IgG}_{2 \mathrm{a}}\right.$, Coulter Immunology, Hialeah, FL) for $\geq 24 \mathrm{~h}$ before assay.
Statistical analysis. Data in text and figures are presented as mean \pm SEM and Student's $t$ tests were used for statistical evaluation.

\section{Results}

Identification of $I L-2 R^{+}$monocytes in AIDS patients. In order to differentiate IL-2 $\mathrm{R}^{+}$monocytes from other circulating cells which might be expressing IL-2R, the MNL were simultaneously stained with FITC-IL-2R (green) and PE-Leu M3 (red). As shown by dual fluorescence FMF, very few $(<1 \%)$ Leu $\mathrm{M3}^{+}, \mathrm{IL}_{-} 2 \mathrm{R}^{+}$cells were present in the MNL from a representative normal subject (Fig. $1 \mathrm{~A}$, left panel). In contrast, the

A
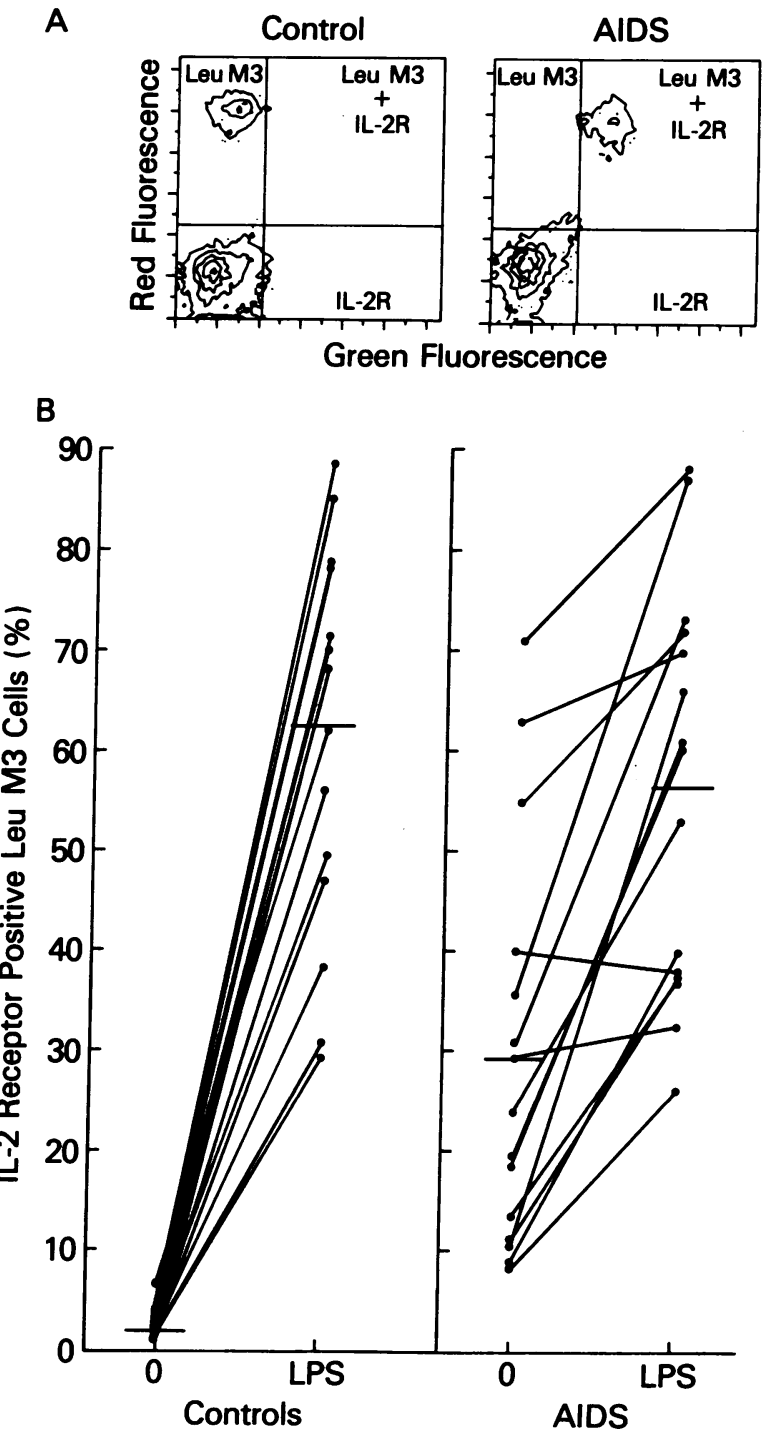

Figure 1. Presence of IL-2R ${ }^{+}$monocytes in AIDS patients and augmentation by LPS. MNL isolated from heparinized peripheral blood of 15 control and AIDS patients were incubated with FITC-conjugated IL-2R (green) and phycoerythrin-conjugated Leu M3 (red) antibodies. After staining, the cells were washed, resuspended in $2 \%$ paraformaldehyde, and analyzed by dual FMF with a FACStar cell sorter. $(A)$ Representative control and AIDS patient dual fluorescence profiles for freshly isolated MNL. (B) Data represent percentage of LeuM3 + cells that express IL-2R before and after incubation with $10 \mu \mathrm{g} / \mathrm{ml}$ LPS for 15 control subjects and 15 AIDS patients. 
majority of the Leu $\mathrm{M}^{+}$monocytes from an AIDS patient analyzed in the same experiment stained positively for IL-2R (Fig. $1 \mathrm{~A}$, right panel). Subsequent analysis of MNL from 15 AIDS patients revealed that $>10 \%$ of the monocytes from all but two of the patients were IL- $2 \mathrm{R}^{+}$, whereas none of the 15 control individuals had $>10 \%$ monocytes that were IL-2 $\mathrm{R}^{+}$ (2.0 $\pm 0.4 \%$ for controls vs. $29.4 \pm 5.2 \%$ for patients; $P<0.001$ ) (Fig. $1 \mathrm{~B}$ ). The levels of IL-2R ${ }^{+}$monocytes did not correlate with the clinical status of the patients, in that patients who were asymptomatic or had only Kaposi's sarcoma, as well as those patients with opportunistic infections, had high levels of IL-2 $\mathrm{R}^{+}$cells. Furthermore, the two individuals with $<10 \%$ IL-2 $\mathbf{R}^{+}$monocytes both had opportunistic infections.

In addition to analysis of freshly isolated monocytes from patients and control subjects for IL-2R expression, monocytes were examined for inducible IL-2R expression (35). In these experiments, aliquots of MNL were incubated for $24 \mathrm{~h}$ in the presence or absence of LPS $(10 \mu \mathrm{g} / \mathrm{ml})$ before phenotypic analysis. Monocytes from control subjects cultured in DME only for $24 \mathrm{~h}$ did not express IL-2R. However, Leu M3 ${ }^{+}$monocytes from all of the control subjects were induced to express significant levels of IL-2R by LPS treatment $(2.0 \pm 0.4 \%$ before vs. $62.5 \pm 5.2 \%$ after LPS; $P<0.001$ ) (Fig. $1 \mathrm{~B}$, left panel).

LPS also enhanced the percentage of IL-2 $\mathrm{R}^{+}$monocytes in the AIDS patients; however, the enhancement was less significant owing to the high levels of receptor already present $\left(29.4 \pm 5.2 \%\right.$ before vs. $56.2 \pm 5.2 \%$ after LPS). Since IL-2R ${ }^{+}$ monocytes are generally not present in normal individuals and appear only as a result of differentiation or activation, the presence of significant numbers of IL-2 $R^{+}$monocytes in the AIDS patients suggests that the cells were activated in vivo.

$I L-2 R$ gene expression in normal and patient monocytes. To determine whether the monocytes from AIDS patients were synthesizing and expressing IL-2R de novo and not just absorbing circulating IL-2R, monocytes from patients with Leu $\mathrm{M3}^{+}$, IL-2R ${ }^{+}$cells were evaluated for IL-2R gene expression. Adherent monocytes from three of these AIDS patients were incubated with or without LPS $(10 \mu \mathrm{g} / \mathrm{ml})$ for $14 \mathrm{~h}$ after which their total RNA was analyzed by Northern hybridization with the IL-2R probe. Similar to previous observations (35), monocytes from a normal subject did not express IL-2R mRNA unless activated (Fig. 2, C). However, the presence of steady-state levels of IL-2R mRNA in the adherent monocytes from the AIDS patients without in vitro activation (Fig. 2, $A 1$, $A 2, A 3)$ indicated that these populations of IL-2 $\mathrm{R}^{+}$cells had been previously activated. Further stimulation of these cells with LPS in vitro minimally augmented the already elevated levels of IL-2R mRNA (Fig. 2). Interestingly, unstimulated monocytes from patient $\mathrm{Al}$ appeared to selectively express the $1.5-\mathrm{kb}$ transcript with little or no expression of the $3.5-\mathrm{kb}$ species. However, after LPS stimulation, both RNA species were expressed in equal proportions. Previous studies indicate that both RNA species encode the functional IL-2R molecule (39).

$H L A-D R$ expression on monocytes from AIDS patients. Since the de novo synthesis and expression of IL-2 receptors have been shown to occur in parallel with increased expression of the class II differentiation antigen, HLA-DR, in populations of stimulated monocytes (35), MNL from the peripheral blood of the AIDS patients were simultaneously evaluated for phenotypic expression of HLA-DR. Although the majority of circulating monocytes from both the control subjects and the

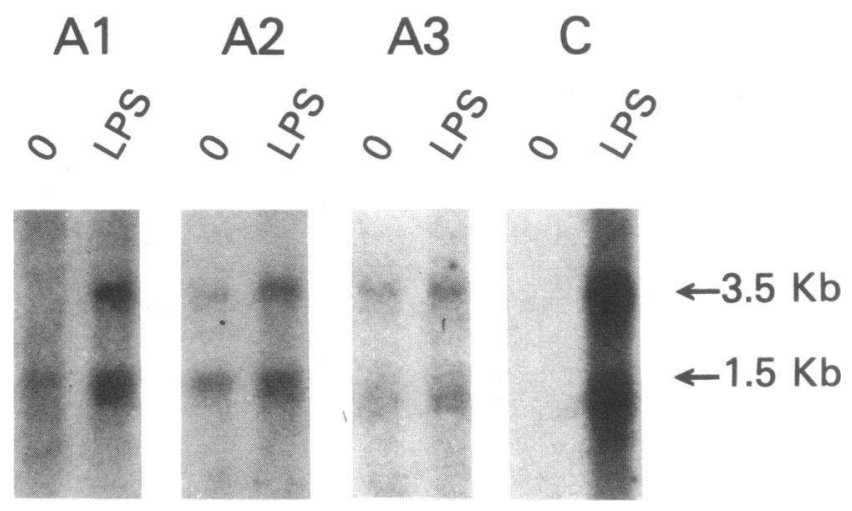

Figure 2. Northern hybridization for IL-2R mRNA in AIDS patients monocytes. Total RNA was extracted by the guanidine thiocyanate method from 5-10 $\times 10^{6}$ adherent MNL from three patients (A1, $\mathrm{A} 2, \mathrm{~A} 3)$ and one control subject $(C)$ cultured with or without LPS for $14 \mathrm{~h}$ and hybridized with a ${ }^{32} \mathrm{P}$-labeled EcoR1 insert of pIL2R2c.

AIDS patients expressed surface HLA-DR (Fig. 3, controls 78.4 $\pm 3.6 \%$; AIDS $89.9 \pm 1.1 \%, n=22$ ), differences were more apparent in the relative median fluorescence intensity (RMFI), a measure of the density of HLA-DR on individual cells (Fig. 3 , right panel). The RMFI was significantly greater on monocytes from AIDS patients (143.9 \pm 5.2$)$ than for similar populations of monocytes from healthy control individuals (98.1 $\pm 3.8 ; P<0.001)$. These observations are consistent with the in vivo activation of AIDS monocytes suggested by the increased expression of IL-2R.

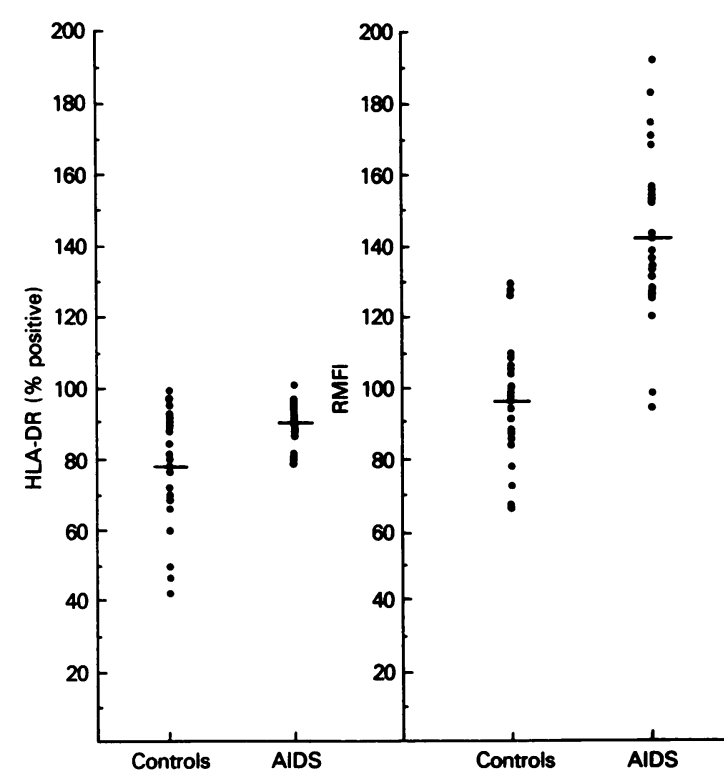

Figure 3. Enhanced HLA-DR expression by monocytes from AIDS patients. MNL from 22 AIDS patients and 22 normal subjects were incubated with FITC-conjugated HLA-DR and PE-conjugated Leu M3 antibodies. After staining, the cells were analyzed by dual FMF. Data represent the percent Leu $\mathrm{M}^{+}$cells which are also HLA-DR ${ }^{+}$. The RMFI is determined by subtracting the background fluorescence (control channel number) from the positive fluorescence (channel number). 
Depletion of $I L-2$ by $I L-2 R^{+}$monocytes from AIDS patients. In light of the observed expression of IL-2R on circulating monocytes from the patients, it was of interest to determine whether these cells might be capable of binding and/or depleting available IL-2. Adherent monocytes from normal subjects and AIDS patients were compared for their ability to deplete biologically active IL-2 added exogenously to their culture media. After the addition of known amounts of IL-2 to IL-2 $\mathrm{R}^{+}$adherent monocytes of AIDS patients, $>40 \%$ of the IL-2 was depleted from the supernatants (Table I), within 48-72 h. No significant IL-2 depletion was detected in the IL-2-containing culture medium of the monocytes from normal subjects or from AIDS patients with $<10 \%$ IL- $2 \mathrm{R}^{+}$monocytes. Thus, the IL-2R ${ }^{+}$monocytes from the AIDS patients appear to provide an effective mechanism for IL-2 reduction.

Effect of in vitro $H I V-1$ infection on monocyte $I L-2 R$ expression. Because of the presence of circulating monocytes expressing IL-2R and enhanced HLA-DR in AIDS patients, we next addressed whether HIV-1 could directly influence the state of monocyte differentiation. Monocytes purified by CCE $\left(>95 \%\right.$ Leu $\mathrm{M3}^{+}$) from normal subjects were exposed to HIV-1 in vitro as described (8), cultured in suspension, and monitored for changes in IL-2R and HLA-DR expression. Phenotypic analysis of these monocytes at different times early after exposure to HIV-1 revealed the appearance of Leu M3 ${ }^{+}$ monocytes expressing IL-2R after $24 \mathrm{~h}$. As shown in Fig. 4, the monocytes cultured in medium only or sham-infected with virus-free macrophage supernatants were IL-2R negative $(<5 \%)$ at each time point throughout the $6 \mathrm{~d}$ of culture. In contrast, $>25 \%$ of the cells exposed to HIV-1 became IL-2R ${ }^{+}$ by day 2 with $>60 \%$ of the monocytes expressing IL-2R within $6 \mathrm{~d}$ after infection. Fluorescence profiles of these populations (Fig. 4, right panels) illustrate the prominent shift in

Table I. Depletion of IL-2 by IL-2R+ Monocytes from AIDS Patients

\begin{tabular}{lc}
\hline IL-2 incubated with & Interleukin 2 \\
& \% of control \\
No cells & $100^{\ddagger}$ \\
AIDS monocytes* & \\
1 & 25 \\
2 & 7 \\
3 & 53 \\
4 & 25 \\
Control monocytes* & \\
1 & 92 \\
2 & 84 \\
3 & 92 \\
4 & 76
\end{tabular}

* Adherent monocytes $\left(2 \times 10^{6} / \mathrm{ml}\right)$ from four AIDS patients and four control subjects were cultured in DME to which was added 100 $\mathrm{U} / \mathrm{ml}$ recombinant IL-2 (Genzyme).

$\ddagger$ Cell-free supernatants ( 48 or $72 \mathrm{~h}$ ) were assayed for IL-2 in the CTLL-2 assay. The units of IL-2 in the individual monocyte supernatants were compared with the units represented in the IL-2 control (100\%) which was incubated under identical conditions with $1 \% \mathrm{AB}$ serum, but without monocytes. No IL-2 was detected in cultures to which no IL-2 was added.

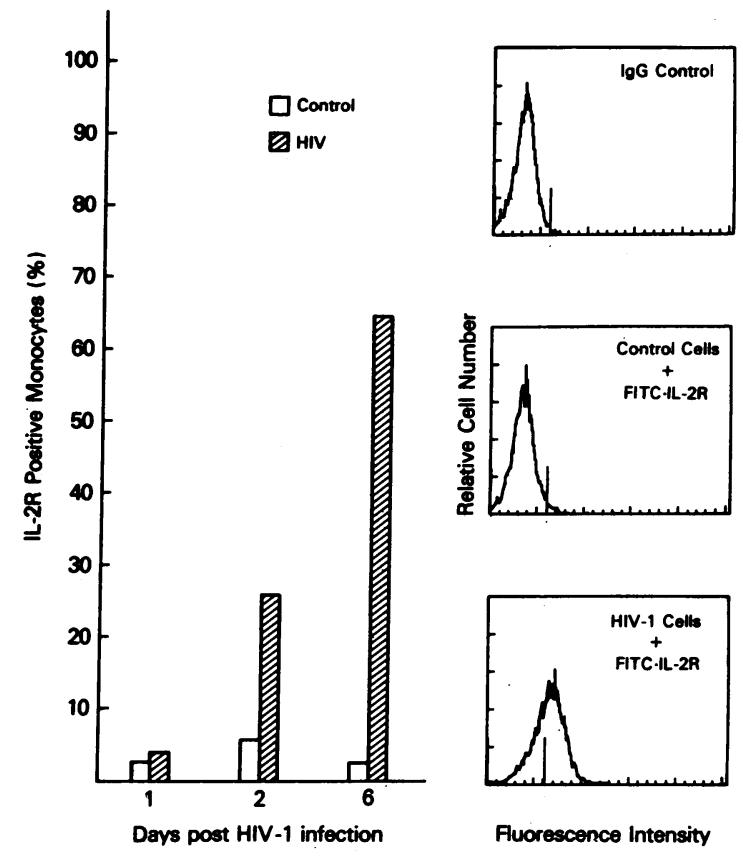

Figure 4. Modulation of IL-2R after exposure to HIV-1. Monocytes were exposed to virus for $1 \mathrm{~h}$, washed, and incubated in RPMI 1640 plus $10 \% \mathrm{FCS}$ at $37^{\circ} \mathrm{C}$ for $1-6 \mathrm{~d}$. At the indicated intervals, monocytes were stained with FITC-IL-2R and analyzed by FMF. The left panel illustrates the percentage of IL-2R positive monocytes (days 1-6 after infection) and the right panel represents histograms of the monocytes stained with FITC-IL-2R $6 \mathrm{~d}$ after culture with (HIV-1 cells) or without (control cells) virus. The IgG control represents monocytes incubated with FITC-IgG only. Data are representative of two separate HIV-1 infections.

IL-2R fluorescence intensity on cells infected with HIV-1. Analysis of HLA-DR expression also demonstrated a parallel increase in the RMFI in HIV-1 infected cells (RMFI 182) compared with control monocytes (RMFI 112) through day 6. To confirm viral infection, cultures were evaluated for p24 levels. Although p24 levels could not be detected in the suspension cultures during the $6 \mathrm{~d}$ of evaluation, long-term cultures of these infected cells maintained under adherence conditions, also negative for p24 at day 6, began to exhibit p24 levels $7 \mathrm{~d}$ after infection $(0.1-0.4 \mathrm{ng} / \mathrm{ml})$ with higher levels by day 14 ( $\geq 5 \mathrm{ng} / \mathrm{ml}$ ). Thus, as previously demonstrated (8), evidence of infection by these parameters could not be documented until $>7 \mathrm{~d}$ after inoculation of the monocytes with HIV-1. By day 10 , as many as $50 \%$ of the monocyte/macrophages in some sections contained intracellular viral particles by ultrastructural analysis. Thus, the phenotypic changes following initial in vitro exposure to HIV-1 appeared to mimic those identified on monocytes from patients with AIDS, including increased HLA-DR expression and synthesis of IL-2 cell surface receptors, but without evidence of productive infection.

Pathway of signal transduction leading to IL-2R expression. In recent studies, we demonstrated that the HIV-1 envelope glycoprotein gp120 as well as antibodies to CD4, both of which bind to the CD4 receptor, stimulate certain monocyte functions $(8,43)$. To determine whether gp120 could effectively induce IL-2R expression on normal monocytes in parallel with augmented HLA-DR, gp120 at the previously deter- 
mined optimal dose of $200-300 \mathrm{ng} / \mathrm{ml}$ was added to CCEenriched monocyte populations. Conservation of the binding region of gp120 in different isolates (44) and previous studies demonstrating monocyte CD4 modulation after gp120 treatment $(8,43)$, suggest that the gp120 from HIV-1/HTLV-III

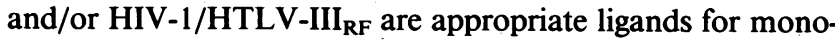
cyte CD4 interactions. The gp120 induced monocyte differentiation as determined by increased HLA-DR (RPMI 122 for gp120-treated monocytes vs. RMFI 109 for controls) and increased surface IL-2R expression (61\% vs. $4 \%$ ) (Fig. 5, top panels). Furthermore, the kinetics of IL-2R expression induced by gp 120 were similar to those for HIV-1-induced IL-2R in that at least $24 \mathrm{~h}$ were required to enable adequate transcription and translation for detection of cell surface receptor expression. The gp120-dependent stimulation of monocytes was blocked by treatment with an antibody to gp120 (Table II) and did not occur in response to another viral product, the core protein p24 (Table II).

Since gp 120 binds to the CD4 receptor, antibodies that bind to the same epitope should mimic the signal transduced by this ligand-receptor interaction. We tested this possibility by evaluating monocytes incubated with antibodies to CD4 for changes in IL-2R and HLA-DR expression. As shown in Fig. 5 (lower panels), both IL-2R expression (42\% after anti-CD4; 4\% for control) and HLA-DR levels (RMFI 125 after antiCD4; RMFI 109 for control) were augmented $24 \mathrm{~h}$ after treatment with $1-3 \mu \mathrm{g} / \mathrm{ml}$ anti-CD4a. Incubation of monocytes with the isotype control did not induce IL-2R expression $(\leq 4 \%)$ or enhancement of HLA-DR. Taken together, this series of experiments indicates that ligand binding to the CD4 receptor on the monocytes may provide an important signal for monocyte differentiation.

\section{Discussion}

In this study we demonstrate the presence of IL- $2 \mathrm{R}^{+}$cells of the monocyte lineage in the peripheral blood of patients with AIDS. This observation may provide insight into the immunopathogenesis of HIV-1 infection. First, the presence of circulating IL-2 $\mathrm{R}^{+}$monocytes indicates that these cells have been activated in vivo since resting monocytes do not express IL-2R. Secondly, the presence on monocytes of IL-2R which can adsorb and therefore deplete IL-2 suggests a plausible mechanism for the reported decrease in IL-2 levels and, possibly, the decrease in $T$ cell proliferative capacity in AIDS patients $(24,25)$. Thirdly, monocyte shedding of IL-2R may contribute to the increased levels of soluble serum IL-2R in AIDS patients (30-33). Finally, modulation of IL-2 $\mathrm{R}^{+}$monocytes by IL-2 may further influence the abnormalities of monocyte function associated with this disease (16).

The ability of HIV-1 to bind to monocytes through their CD4 receptors and to induce the expression of cellular genes, particularly those encoding differentiation markers such as IL-2R and HLA-DR, likely contributes to the immunopathogenesis of AIDS. Our in vitro observations are consistent with the increased expression of activation markers present on circulating monocytes in some AIDS patients $(8,16,18)$. Furthermore, these data provide a rational basis for the paradox of a cell population which is phenotypically differentiated, but functionally impaired $(8,25,45-47)$. Monocytes infected with

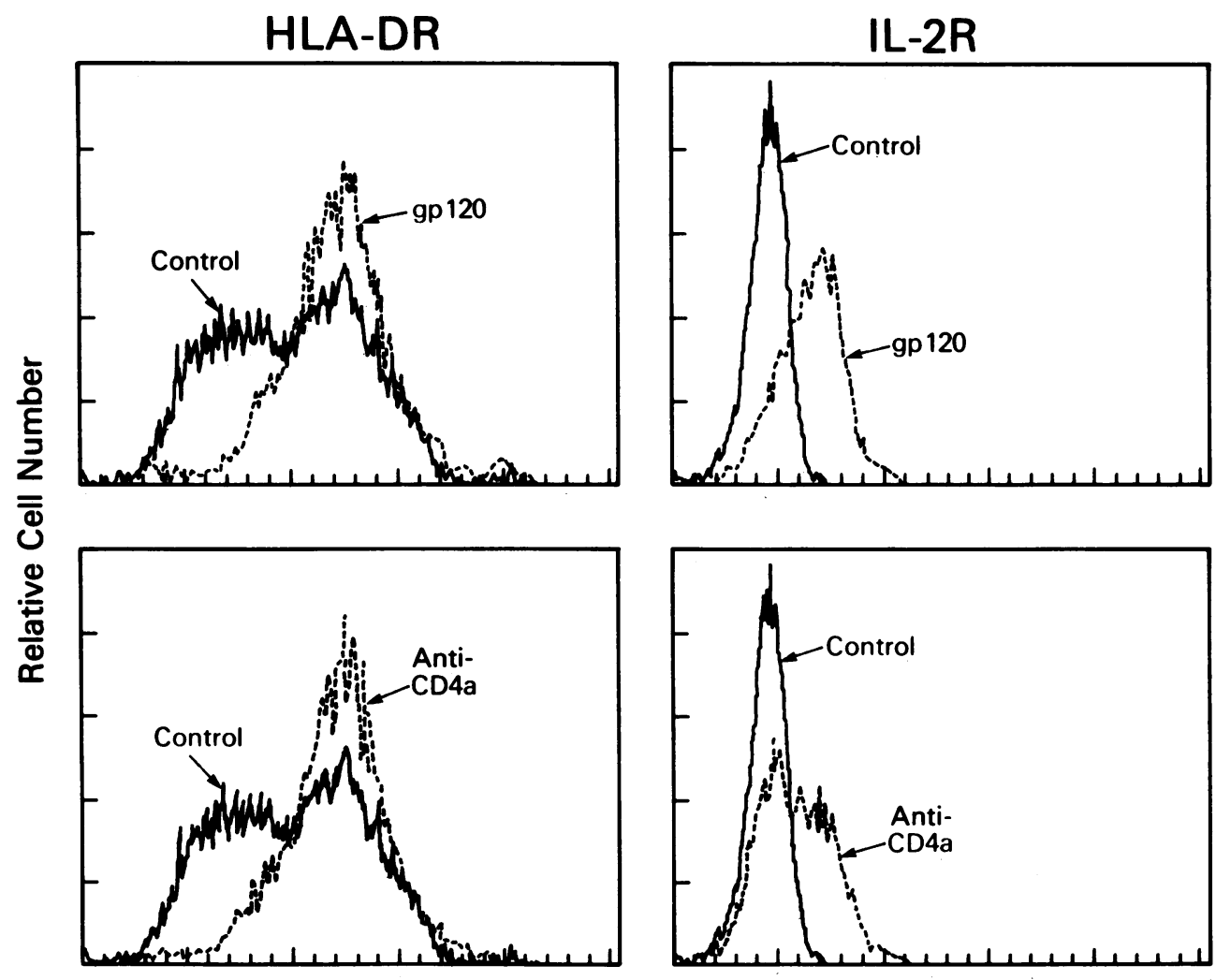

Fluorescence Intensity
Figure 5. Modulation of HLA-DR and IL-2R by gp 120 and antiCD4a. CCE-purified monocytes were incubated with medium only

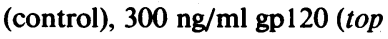
panels), or $2.5 \mu \mathrm{g}$ anti-CD4a (bottom panels) for $24 \mathrm{~h}$ before staining with FITC-HLA-DR or FITCIL-2R. The cells were then analyzed by FMF. Data are representative of three experiments. 
Table II. Specificity of gp120 Stimulation of Peripheral Blood Monocytes

\begin{tabular}{|c|c|c|}
\hline \multirow[b]{2}{*}{ Treatment* } & \multicolumn{2}{|c|}{$\mathrm{IL}^{-2 \mathrm{R}^{\ddagger}}$} \\
\hline & Experiment 1 & Experiment 2 \\
\hline & \multicolumn{2}{|c|}{$\%$ positive } \\
\hline Control & 2.5 & 5.4 \\
\hline gp120 & 26.4 & 24.8 \\
\hline gp $120+$ anti-gp120 & 3.9 & 2.5 \\
\hline p24 & 5.9 & 3.3 \\
\hline
\end{tabular}

* Monocytes (> 95\% Leu M3 ${ }^{+}$) were incubated with $200 \mathrm{ng} / \mathrm{ml}$ (experiment 1 ) or $300 \mathrm{ng} / \mathrm{ml}$ (experiment 2) gp 120, an equivalent concentration of gp120 pre-treated with anti-gp 120, purified p24 (300 $\mathrm{ng} / \mathrm{ml}$ ), or with medium only (control) for $24 \mathrm{hr}$.

‡ Monocytes were washed, stained with FITC-IL-2R, and analyzed by FMF for IL-2R expression. Data represent the percentage IL-2R ${ }^{+}$ cells in each experiment.

HIV-1 may undergo premature differentiation and consequently become refractory to activation by a second immunologic stimulus. Moreover, infection may not be the only route of monocyte differentiation since we show that soluble gp120 can mimic these effects on monocytes. Shedding of soluble gp120, which might be especially evident in a localized area of infection such as in the brain, could provide a concentrated source of monocyte triggering signals. Furthermore, other pathogens (cytomegalovirus) and/or cytokines (interferons) may promote local monocyte differentiation. Monocytes stimulated by HIV-1 or viral products also spontaneously generate inflammatory mediators including tumor necrosis factor, interleukin 6 and interleukin 1 (McCartney-Francis, N., personal communication; 21,48 ), which promote fever and other metabolic effects. However, as the responsive $\mathrm{T}$ cell population is depleted, these monocyte products may become ineffective in promoting host defense.

The AIDS virus may infect cells of the monocyte/macrophage lineage before infection of $T$ lymphocytes (49). Our observations offer, in part, a mechanism for enhancement of monocyte-T cell interactions and consequently, the possible transfer of virus from monocytes to $\mathrm{CD}^{+}$lymphocytes. First, increased HLA-DR expression on monocytes after exposure to $\mathrm{HIV}-1$ would promote monocyte-CD4 ${ }^{+} \mathrm{T}$ cell interactions since helper/inducer $\mathrm{T}$ cells recognize antigens in association with MHC class II HLA determinants (50). Secondly, spontaneous release of IL-1 by the HIV-1-infected monocytes (21) would also promote $\mathrm{T}$ cell proliferation and consequently replication of the virus in the T cells (49). Increased expression and/or release of virus and gp 120 could then infect or activate additional monocytes. This cycle of monocyte-T lymphocyte interaction may persist with continued $\mathrm{T}$ cell infection and depletion. Furthermore, as the monocyte/macrophages become productively infected by HIV-1, they may become functionally deficient (McCartney-Francis, N., personal communication) with decreased HLA-DR expression as has been observed in some patient studies (19).

In summary, our study provides evidence in support of the recently proffered hypothesis $(51,52)$ that infection of monocytes by HIV-1 leads initially to activation and/or overstimu- lation of the immune system. Activation of $\mathrm{CD}^{+}, \mathrm{HIV}-1^{+} \mathrm{T}$ cells ultimately results in destruction of this population and immunosuppression. Based on this concept, attempts to selectively kill the infected cells in conjunction with antiviral therapy which inhibits HIV-1 in monocytes $(53,54)$ as well as in T cells, offers a rational approach for therapeutic modulation of the immune system in the acquired immunodeficiency syndrome.

\section{Acknowledgments}

The authors are grateful to Dr. W. Leonard, National Institutes of Health for the IL-2R probe, Dr. Janos Szebeni for p24 determinations, and to Ms. Sue Dougherty, Diane Mizel, Sandra Resto-Ruiz, Marta Corcoran, and Mr. Glenn Welch for their valuable contributions to this study. The authors also thank Drs. H. Clifford Lane, Anthony Fauci, and Henry Masur for providing clinical care for the patients at the National Institutes of Health. Soluble HIV-1 gp 120, antibody to gp120, and p24 were kindly provided by Drs. Stephen W. Pyle and Larry O. Arthur, AIDS Vaccine Program, Program Resources, Inc., National Cancer Institute-Frederick Cancer Research Facility, Frederick, MD under contract no. N01-CO-74102.

\section{References}

1. Dalgleish, A. G., P. C. Beverley, P. R. Clapham, D. H. Crawford, F. M. Greaves, and R. A. Weiss. 1984. The CD4 (T4) antigen is an essential component of the receptor for the AIDS retrovirus. Nature (Lond.). 312:763-767.

2. Klatzmann, D., E. Champagne, S. Chamaret, J. Gruest, D. Guetard, T. Hercend, J. C. Gluckman, and L. Montagnier. 1984. Tlymphocyte $\mathrm{T} 4$ molecule behaves as the receptor for human retrovirus LAV. Nature (Lond.). 312:767-768.

3. McDougal, J. S., M. S. Kennedy, J. M. Sligh, S. P. Cort, A. Mawle, and J. K. Nicholson. 1986. Binding of HTLV-III/LAV to T4 ${ }^{+}$ $\mathrm{T}$ cells by a complex of the $110 \mathrm{~K}$ viral protein and the T4 molecule. Science (Wash. DC). 231:382-385.

4. Nicholson, J. K., G. D. Cross, C. S. Callaway, and J. S. McDougal. 1986. In vitro infection of human monocytes with human T lymphotropic virus type III/lymphadenopathy-associated virus (HTLVII/LAV). J. Immunol. 137:323-329.

5. Gendelman, H. E., J. M. Orenstein, M. A. Martin, C. Ferrua, R. Mitra, T. Phipps, L. M. Wahl, H. C. Lane, A. S. Fauci, D. S. Burke, D. Skillman, and M. S. Meltzer. 1988. Efficient isolation and propagation of human immunodeficiency virus on recombinant colony-stimulating factor 1-treated monocytes. J. Exp. Med. 167:1428-1441.

6. Gartner, S., P. Markovits, D. M. Markovitz, M. H. Kaplan, R. C. Gallo, and M. Popovic. 1986. The role of mononuclear phagocytes in HTLV-III/LAV infection. Science (Wash. DC). 233:215-219.

7. Ho, D. D., T. R. Rota, and M. S. Hirsch. 1986. Infection of monocyte/macrophages by human $\mathrm{T}$ lymphotropic virus type III. $J$. Clin. Invest. 77:1712-1715.

8. Wahl, S. M., J. B. Allen, S. Gartner, J. M. Orenstein, M. Popovic, D. E. Chenoweth, L. O. Arthur, W. L. Farrar, and L. M. Wahl. 1989. Human immunodeficiency virus-1 and its envelope glycoprotein down-regulate chemotactic ligand receptors and chemotactic function of peripheral blood monocytes. J. Immunol. 142:3553-3559.

9. Epstein, L. G., L. R. Sharer, E. S. Cho, M. Myenhofer, B. A Navia, and R. W. Price. 1984. HTLV-III/LAV-like retrovirus particles in the brains of patients with AIDS encephalopathy. AIDS Res. $1: 447-454$.

10. Koenig, S., H. E. Gendelman, J. M. Orenstein, M. C. Dal Canto, G. H. Pezeshkpour, M. Yungbluth, F. Janotta, A. Aksamit, M. A. Martin, and A. S. Fauci. 1986. Detection of AIDS virus in macrophages in brain tissue from AIDS patients with encephalopathy. Science (Wash. DC). 233:1089-1093. 
11. Gartner, S., P. Markovits, D. M. Markovitz, R. F. Betts, and M Popovic. 1986. Virus isolation from and identification of HTLV-III/ LAV-producing cells in brain tissue from a patient with AIDS. JAMA (J. Am. Med. Assoc.) 256:2365-2371.

12. Wiley, C. A., R. D. Schrier, J. A. Nelson, P. W. Lampert, and M. A. Oldstone. 1986. Cellular localization of human immunodeficiency virus infection within brains of AIDS patients. Proc. Natl. Acad. Sci. USA. 83:7089-7093.

13. Salahuddin, S. Z., R. M. Rose, J. E. Groopman, P. D. Markham, and R. C. Gallo. 1986. Human T lymphotropic virus type III (HTLV-II) infection of human alveolar macrophages. Blood. 68:281284.

14. Tschachler, E., V. Groh, M. Popovic, D. L. Mann, K. Konrad, B. Safai, L. Eron, F. di Marzo Veronese, K. Wolff, and G. Stingl. 1987. Epidermal Langerhans cells-A target for HTLV-III/LAV infection. $J$. Invest. Dermatol. 88:233-237.

15. Levy, J. A., J. Shimabukuro, T. McHugh, C. Casavant, D. P. Stites, and L. S. Oshiro. 1985. AIDS-associated retrovirus (ARV) can productively infect other cells besides human $\mathrm{T}$ helper cells. Virology 147:441-448

16. Roy, S., and M. A. Wainberg. 1988. Role of the mononuclear phagocyte system in the development of acquired immunodeficiency syndrome (AIDS). J. Leuk. Biol. 43:91-97.

17. Edelman, A. S., and S. Zolla-Pazner. 1989. AIDS: a syndrome of immune dysregulation, dysfunction, and deficiency. FASEB (Fed. Am. Soc. Exp. Biol.) J. 3:22-30.

18. Sei, Y., R. J. Petrella, P. Tsang, J. G. Bekesi, and M. M. Yokoyama. 1986. Monocytes in AIDS. N. Engl. J. Med. 315:1611-1612.

19. Heagy, W., V. E. Kelley, T. B. Strom, K. Mayer, H. M. Shapiro R. Mandel, and R. Finberg. 1984. Decreased expression of human class II antigens on monocytes from patients with acquired immune deficiency syndrome. Increased expression with interferon- $\gamma . J$. Clin. Invest. 74:2089-2096.

20. Smith, P. D., K. Ohura, H. Masur, H. C. Lane, A. S. Fauci, and S. M. Wahl. 1984. Monocyte function in the acquired immune deficiency syndrome: Defective chemotaxis. J. Clin. Invest. 74:2121-2128.

21. Berman, M. A., C. I. Sandborg, B. S. Calabia, B. S. Andrews, and G. J. Friou. 1987. Interleukin 1 inhibitor masks high interleukin 1 production in acquired immunodeficiency syndrome (AIDS). Clin. Immunol. Immunopathol. 42:133-140.

22. Roux-Lombard, P., D. Aladjem, J.-F. Balavoine, M. Chofflon J.-P. Despont, B. Hirschel, M. Jeannet, Y. Kapanci, R. Lang, M.-F Toccanier, B. Voinier, A. Wilhelm, J.-M. Dayer, and A. Cruchaud. 1986. Altered functions of peripheral blood monocytes in homosexual males and intravenous drug users with persistent generalized lymphadenopathy. Eur. J. Clin. Invest. 16:262-270.

23. Locksley, R. M., S. Crowe, M. D. Sadick, F. P. Heinzel, K. D. Gardner, M. S. McGrath, and J. Mills. 1988. Release of interleukin-1 inhibitory activity (contra-IL-1) by human monocyte-derived macrophages infected with human immunodeficiency virus in vitro and in vivo. J. Clin. Invest. 82:2097-2105.

24. Prince, H. E., D. J. Moody, B. I. Shubin, and J. L. Fahey. 1985. Defective monocyte function in acquired immune deficiency syndrome (AIDS): evidence from a monocyte-dependent $T$ cell proliferation system. J. Clin. Immunol. 5:21-25.

25. Shannon, K., M. J. Cowan, E. Ball, D. Abrams, P. Volberding, and A. J. Ammann. 1985. Impaired mononuclear cell proliferation in patients with the acquired immune deficiency syndrome results from abnormalities of both $\mathrm{T}$ lymphocytes and adherent mononuclear cells. J. Clin. Immunol. 5:239-245.

26. Prince, H. E., V. Kermani-Arab, and J. L. Fahey. 1984. Depressed interleukin 2 receptor expression in acquired immune deficiency and lymphadenopathy syndromes. J. Immunol. 133:13131317.

27. Tsang, K. Y., H. H. Fudenberg, G. M. P. Galbraith, R. P. Donnelly, L. R. Bishop, and W. R. Koopman. 1985. Partial restoration of impaired interleukin- 2 production and Tac antigen (putative interleukin-2 receptor) expression in patients with acquired immune deficiency syndrome by isoprinosine treatment in vitro. J. Clin. Invest. 75:1538-1544.

28. Maggi, E., D. Maechia, P. Parronchi, M. Mazzetti, A. Ravina, D. Milo, and S. Romagnani. 1987. Reduced production of interleukin 2 and interferon-gamma and enhanced helper activity for IgG synthesis by cloned $\mathrm{CD}^{+} \mathrm{T}$ cells from patients with AIDS. Eur. J. Immunol. 17:1685-1690.

29. Robb, R. J., and R. M. Kutny. 1987. Structure-function relationships for the IL-2 receptor system. Analysis of the sequence and ligand-binding properties of soluble Tac protein. J. Immunol. 139:855-862.

30. Prince, H. E., S. Kleinman, and A. E. Williams. 1988. Soluble IL-2 receptor levels in serum from blood donors seropositive for HIV. J. Immunol. 140:1139-1141.

31. Sethi, K. K., and H. Naher. 1986. Elevated titers of cell-free interleukin-2 receptor in serum and cerebrospinal fluid specimens of patients with acquired immunodeficiency syndrome. Immunol. Lett. 13:179-184.

32. Kloster, B. E., P. A. John, L. E. Miller, L. A. Rubin, D. L. Nelson, D. C. Blair, and R. H. Tomar. 1987. Soluble interleukin-2 receptors are elevated in patients with AIDS or at risk of developing AIDS. Clin. Immunol. Immunopathol. 45:440-446.

33. Reddy, M. M., and M. H. Grieco. 1988. Elevated soluble interleukin-2 receptor levels in serum of human immunodeficiency virus infected populations. AIDS Res. Hum. Retrovir. 4:115-120.

34. Herrmann, F., S. A. Cannistra, H. Levine, and J. D. Griffin. 1985. Expression of interleukin-2 receptors and binding of interleukin-2 by gamma interferon-induced human leukemic and normal monocytic cells. J. Exp. Med. 162:1111-1116.

35. Wahl, S. M., N. McCartney-Francis, D. A. Hunt, P. D. Smith, L. M. Wahl, and I. M. Katona. 1987. Monocyte interleukin-2 receptor gene expression and interleukin-2 augmentation of microbicidal activity. J. Immunol. 139:1342-1347.

36. Holter, W., C. K. Goldman, L. Casabo, D. L. Nelson, W. C. Greene, and T. A. Waldmann. 1987. Expression of functional IL-2 receptors by lipopolysaccharide and interferon- $\gamma$ stimulated human monocytes. J. Immunol. 138:2917-2922.

37. Rubin, L. A., C. C. Kurman, M. E. Fitz, W. E. Biddison, B. Boutin, R. Yarchoan, and D. L. Nelson. 1985. Soluble interleukin-2 receptors are released from activated human lymphoid cells in vitro. $J$. Immunol. 135:172-177.

38. Wahl, L. M., I. M. Katona, R. L. Wilder, C. C. Winter, B. Haraoui, I. Scher, and S. M. Wahl. 1984. Isolation of human mononuclear cell subsets by counterflow centrifugal elutriation I. Characterization of B lymphocyte, T lymphocyte and monocyte enriched fractions by flow cytometric analysis. Cell. Immunol. 85:373-383.

39. Leonard, W. J., J. M. Depper, G. R. Crabtree, S. Rudikoff, J. Pumphrey, R. J. Robb, M. Kronke, P. B. Svetlik, M. J. Peffer, T. A. Waldmann, and W. C. Greene. 1984. Molecular cloning and expression of cDNAs for the human interleukin-2 receptor. Nature (Lond.). 311:626-631.

40. Wahl, S. M., D. A. Hunt, H. L. Wong, S. Dougherty, N. McCartney-Francis, L. M. Wahl, L. Ellingsworth, J. A. Schmidt, G. Hall, A. B. Roberts, and M. B. Sporn. 1988. Transforming growth factor- $\beta$ is a potent immunosuppressive agent that inhibits IL-1-dependent lymphocyte proliferation. J. Immunol. 140:3026-3032.

41. Pyle, S. W., G. C. Dubois, W. G. Robey, J. W. Bess, Jr., P. J. Fischinger, and L. O. Arthur. 1988. Purification and characterization of the external envelope glycoprotein from two human immunodeficiency virus type 1 variants, $\mathrm{HTLV}-\mathrm{III}_{\mathrm{B}}$ and $\mathrm{HTLV}-\mathrm{III}_{\mathrm{RF}}$. J. Virol. 62:2258-2264.

42. Kalyanaraman, V. S., M. G. Sarngadharan, B. Poiesz, F. W. Ruscetti, and R. C. Gallo. 1981. Immunological properties of a type C retrovirus isolated from cultured human T-lymphoma cells and comparison to other mammalian retroviruses. J. Virol. 38:906-915. 
43. Wahl, L. M., M. L. Corcoran, S. W. Pyle, L. O. Arthur, A. Harel-Bellan, and W. L. Farrar. 1989. Human immunodeficiency virus glycoprotein (gp120) induction of monocyte arachidonic acid metabolites and interleukin-1. Proc. Natl. Acad. Sci. USA. 86:621625.

44. Lasky, L. A., G. Nakamura, D. H. Smith, C. Kennie, C. Shimaski, E. Patzer, P. Berman, T. Gregory, and D. J. Capon. 1987. Delineation of a region of the human immunodeficiency virus type 1 gp 120 glycoprotein critical for interaction with the CD4 receptor. Cell. 50:975-985.

45. Estevez, M. E., I. J. Ballart, R. A. Diez, N. Planes, C. Scaglione, and L. Sen. 1986. Early defect of phagocytic cell function in subjects at risk for acquired immunodeficiency syndrome. Scand. J. Immunol. 24:215-221.

46. Fauci, A. S. 1984. Immunologic abnormalities in the acquired immunodeficiency syndrome (AIDS). Clin. Res. 32:491-499.

47. Poli, G., B. Botazzi, R. Acero, L. Bersani, V. Rossi, M. Introna, A. Lazzarin, M. Galli, and A. Mantovani. 1985. Monocyte function in intravenous drug abusers with lymphadenopathy syndrome and in patients with acquired immunodeficiency syndrome: selective impairment of chemotaxis. Clin. Exp. Immunol. 62:136-142.

48. Nakajima, K., O. Martinez-Maza, T. Hirano, E. C. Breen, P. G. Nishanian, J. F. Salazar-Gonzalez, J. L. Fahey, and T. Kishimoto. 1989. Induction of IL-6 (B cell stimulatory factor- $2 / \mathrm{IFN}-\beta_{2}$ ) production by HIV. J. Immunol. 142:531-536.
49. Popovic, M., E. Read-Connole, and S. Gartner. 1988. Biological properties of HTLV-III/LAV: A possible natural infection in vivo. Ann. Inst. Pasteur Immunol. 137:413-417.

50. Buus, S., A. Settem, S. M. Colon, C. Miles, and H. M. Grey. 1987. The relation between major histocompatibility complex (MHC) restriction and the capacity of Ia to bind immunogenic peptides. Science (Wash. DC). 235:1353-1358.

51. Ascher, M. S., and H. W. Sheppard. 1988. AIDS as an immune system activation: a model for pathogenesis. Clin. Exp. Immunol. 73:165-167.

52. Pauza, C. D. 1988. HIV persistence in monocytes leads to pathogenesis and AIDS. Cell. Immunol. 112:414-424.

53. Perno, C.-F., R. Yarchoan, D. A. Cooney, N. R. Hartman, S. Gartner, M. Popovic, Z. Hao, T. L. Gerrard, Y. A. Wilson, D. G. Johns, and S. Broder. 1988. Inhibition of human immunodeficiency virus (HIV-I/HIV-III ${ }_{\mathrm{Ba}-\mathrm{L}}$ ) replication in fresh and cultured human peripheral blood monocytes/macrophages by azidothymidine and related 2',3'-dideoxynucleosides. J. Exp. Med. 168:1111-1125.

54. Szebeni, J., S. M. Wahl, M. Popovic, L. M. Wahl, S. Gartner, R. L. Fine, U. Skaleric, R. M. Friedman, and J. N. Weinstein. 1989. Dipyridamole potentiates the inhibition by azidothymidine and other dideoxynucleosides of human immunodeficiency virus replication in monocyte/macrophages. Proc. Natl. Acad. Sci. USA. 86:3842-3846. 